\title{
Uncaria tomentosa and Uncaria guianensis an agronomic history to be written
}

\author{
Uncaria tomentosa e Uncaria guianensis uma história agronômica a ser escrita
}

\author{
Isabela Cristina Gomes Honório ${ }^{I}$ Bianca Waléria Bertoni ${ }^{I I}$ Ana Maria Soares Pereira ${ }^{\text {II }}$
}

\begin{abstract}
The Uncaria tomentosa and Uncaria guianensis species, which are endemic plants in the Amazonian region, are highlighted as medicinal plants mainly because of their anti-inflammatory activity. The vegetal drug and various types of extracts have been commercialized by pharmaceutical industries and distributed in several countries, thus configuring the economic potential of both species. The objective of the present research was to collect agronomical data published in PubMed, SciELO, and Scopus databases and analyze the main subjects that were either investigated or not investigated to enable the production chain of these species. The conclusion is that $\boldsymbol{U}$. guianensis has been less studied than $\boldsymbol{U}$. tomentosa under all aspects evaluated. Both species have been exploited in an extractivistic way. However, no report was found on either sustainable management or conservation or domestication strategies or yet large scale production that can continuously attend the global demand of the pharmaceutic industry. Furthermore, the amount currently produced is insufficient to supply the program of the Ministry of Health, which intends to provide herbal drugs from Uncaria to all Brazilian cities.
\end{abstract}

- REVIEW
Key words: Uncaria, cat's claw, medicinal plants, extractivism.

\section{RESUMO}

As espécies Uncaria tomentosa e Uncaria guianensis, plantas endêmicas da Amazônia, destacam-se como plantas medicinais por apresentarem principalmente atividade anti-inflamatória. A droga vegetal e diversos tipos de extratos são comercializadas por indústrias farmacêuticas distribuidas em vários países, configurando o potencial econômico de ambas as espécies. $O$ objetivo deste trabalho foi reunir dados agronômicos publicados nas bases de dados PubMed, SciELO e Scopus para analisar os principais temas que já foram investigados ou que ainda precisam ser abordados para viabilizar a cadeia produtiva dessas espécies. A conclusão é que $\boldsymbol{U}$. guianensis é menos estudada do que $\boldsymbol{U}$. tomentosa sob todos os aspectos avaliados. Ambas as espécies são exploradas de forma extrativista. Entretanto, não foram encontrados relatos de manejo sustentável, nem estratégias de conservação ou domesticação, ou ainda plantios em larga escala que possam atender de modo contínuo a demanda mundial da indústria farmacêutica. Além disso, não há quantidade suficiente para abastecer o programa nacional do Ministério da Saúde, que pretende disponibilizar fitoterápicos produzidos a partir de Uncaria a todos os municípios brasileiros.

Palavras-chave: Uncaria, unha de gato, plantas medicinais, extrativismo.

\section{INTRODUCTION}

Mankind has always found solutions to its health problems in nature. The use of plants in the treatment and cure of diseases is as old as the human species. For millennia, medicinal plants corresponded to about $90 \%$ of the medications used to the relief and healing of diseases (CUNHA et al., 2003).

Data from the World Health Organization (WHO) showed that at some point of life about $80 \%$ of the world population has used a medicinal plant in the search for relief from some unpleasant symptom, and at least $30 \%$ of them were prescribed by physicians (MARTINS et al., 2003). In the early 1990s, the WHO reported that $65-80 \%$ of the population in developing countries depends on medicinal plants as the only way to access for basic healthcare (VOLPATO, 2005). In

\footnotetext{
'Universidade Estadual Paulista “Júlio de Mesquita Filho” (UNESP), Campus Botucatu, Fazenda Lageado, Rua José Barbosa de Barros, $\mathrm{n}^{\circ}$ 1780, 18610-307, Botucatu, SP, Brasil. E-mail: isabelagomeshonorio@gmail.com. Corresponding author.

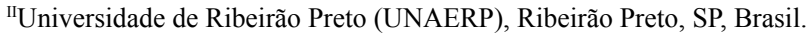


addition, the WHO also recognizes that traditional knowledge on biodiversity products is an important tool to develop new drugs. They are expected to be useful in fighting diseases that afflict populations who live in developing countries (WORLD HEALTH ORGANIZATION, 2003).

Tropical forests, which are located in developing countries such as Brazil, are the major sources of biodiversity. These forests represent about one third of the world flora. However, countries such as USA, Japan, and some in Europe were those that most profited from the trade of natural products from these forests (KLEIN et al., 2009). Tropical forests have half of about 500,000 species of plants estimated to exist in the world, and less than $1 \%$ of them were researched for pharmacological activity (MARTINS et al., 2003).

Species from the genus Uncaria, which are among plants with a significant therapeutic and economic potential, occur in tropical forests, especially in Amazonia. This genus includes the tribe Coptosapelteae (LAUS, 2004), specifically subtribe Mitragyninae (KEPLINGER et al., 1999), subfamily Cinchonoidae (MUR et al., 2002), and family Rubiaceae.

Among botanists, there is not yet consensus regarding the number of species that compose the genus Uncaria. However, DWYER (1980), SHULTES et al., (1990), and SOUKUP (1987) mention that there are 60, and GENTRY (1993) reports that 50 species.

The genus Uncaria includes species with an expressive medicinal potential, e.g., $\boldsymbol{U}$. formosana, $U$. guianensis, $U$. macrophylla, $U$. rhynchophylla, $U$. sinensis and $U$. tomentosa (FALKIEWICZ \& LUKASIAK, 2001). $\boldsymbol{U}$. guianensis e $\boldsymbol{U}$. tomentosa are among the most commercialized species worldwide.

The species $\boldsymbol{U}$. guianensis is found in areas between the $08^{\circ} 04^{\prime} 00^{\prime \prime} \mathrm{N}-17^{\circ} 32^{\prime} 00^{\prime \prime} \mathrm{S}$ and 44'56'00"E - 78 25"42"W coordinates (altitudes: 7-1010m), in Bolivia, Brazil, Colombia, Ecuador, Guyana, French Guyana, Peru, Suriname, and Venezuela. Whereas $\boldsymbol{U}$. tomentosa is distributed

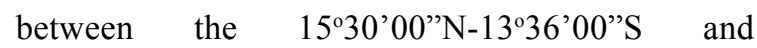
$51^{\circ} 58^{\prime} 00^{\prime} \mathrm{E}-89^{\circ} 00^{\prime} 00^{\prime \prime} \mathrm{W}$ coordinates (altitudes: 5-750m), in areas including Belize, Bolivia, Brazil, Colombia, Costa Rica, Ecuador, Guatemala, Guyana, French Guyana, Honduras, Nicaragua, Panama, Peru and Venezuela (ZEVALLOS-POLLITO \& TOMAZELLO FILHO, 2010). In Brazil, the species $\boldsymbol{U}$. guianensis is found in the States of Acre, Amazonas, Amapá, Maranhão, Mato Grosso,
Pará, Rondônia, Roraima, and Tocantins; whereas, U. tomentosa is mainly distributed in the States of Acre, Amapá, Amazonas, and Pará (PEREIRA \& LOPES, 2006).

These species are typical of tropical and subtropical humid climates, needing favorable weather conditions (temperatures: $17.0-25.7^{\circ} \mathrm{C}$; rainfalls: $1200-6000 \mathrm{~mm}$ ) during the year for their development (ZEVALLA \& ZEVALLOS, 1996). They develop in soils of alluvial origin and sandy loam or open clay texture (SHUNKE, 1998), with $\mathrm{pH}$ values ranging from strongly acidic to slightly alkaline, abundant organic matter in poorly drained or flooded areas (ZEVALLOS et al., 2000).

They grow in various geo environments, and the mean number of individuals per hectare is variable in floodplain (33), secondary forest (10.7) and mainland (1.7) (MIRANDA et al., 2001). The species $\boldsymbol{U}$. tomentosa occurs in soils rich in organic matter, areas of primary forests, salt marshes and banks of watercourses; whereas, $U$. guianensis grows in secondary forests, riverbanks and roads. This species has a high capacity to colonize anthropized and degraded areas, being considered invader in abandoned pasture areas. In Brazilian regions where $\boldsymbol{U}$. guianensis occurs naturally, it is found more abundantly and frequently than the species $\boldsymbol{U}$. tomentosa (GUEVARA, 1995; MIRANDA et al., 2001).

Both species are used by traditional people in Amazonia in the treatment of various diseases such as asthma, arthritis, dermatitis, diabetes, gastritis, gonorrhea, inflammation of the genitourinary tract, irregularity in the menstrual cycle, viral processes, tumors (benign and malignant), and ulcers (VILCHES, 1997).

Although they are widely mentioned in ethnopharmacological surveys, data collected in the PubMed showed that the species $\boldsymbol{U}$. tomentosa has been studied for a longer period (1974-2014) and the numbers of studies published are greater (164) and researches have been led by the USA (34) and followed by Brazil (21). Articles published with U. guianensis are more recent (1983-2014) and a smaller number (14) as compared to U. tomentosa, and the United States (3) and Brazil (3) are also the countries that most published on this species (PUBMED, 2014). According to the SciELO database, 40 studies were published on $U$. tomentosa (29) and $\boldsymbol{U}$. guianensis (11). These numbers are also reported in the Scopus database.

Pharmacological studies conducted with extracts from $\boldsymbol{U}$. guianensis and $\boldsymbol{U}$. tomentosa 
confirmed their antioxidant, anti-diabetic, antimicrobial, anti-inflammatory, immunostimulant, anticancer, and anti-Parkinson's disease effects (ZHANG et al., 2015).

Alkaloids are the most important group of secondary metabolites reported in the species $\boldsymbol{U}$. guianensis and $\boldsymbol{U}$. tomentosa. They are divided into indole tetracyclic alkaloids (corynanthein, dihydrocorynanthein, hirsuthein, andhirsutine)oxindole alkaloids (rhynchophylline, isorhynchophylline, corynoxein, isocorynoxein, rotundifolin, and isorotundifolin) indole pentacyclic alkaloids (akuamigine, augustine, augustolin, isoamalicin, and tetrahydroalstonin) and oxindole alkaloids (speciophylline, mitraphylline, isomitraphylline, pteropodin, isopteropodin, and uncarin F), and glycoindole alkaloids (3 $\alpha$-dihydrocadambine and dolichantosin) (LAUS et al., 1997; FALKIEWICZ \& LUKASIAK, 2001; LUNA-PALENCIA et al., 2013). Besides the alkaloids, the triterpenic heterosides (derived from the quinovic acid) and polyphenols (especially tannin) are also highlighted (PAVEI et al., 2012; SHENG et al., 2005).

In $\boldsymbol{U}$. tomentosa, the alkaloids are distributed in flowers $(2.10 \%)$, leaves $(1.59 \%)$, stem bark $(0.50 \%)$, branches with thorns $(0.32 \%)$ (QUIROZ et al., 2004), and root (1.00-2.00\%) (REINHARD, 1999). PEÑALOZA et al. (2015) conducted a study with access of $\boldsymbol{U}$. tomentosa collected in situ in Peru and showed that the content of oxindole alkaloids varied significantly among individuals, in both stem bark $(0.328-2.591 \%)$, sheets $(0.360-4.792 \%)$ and branches $(0.347-1.431 \%)$.

The fact that individuals, that produce much more alkaloids in the leaves than in the stem bark, have been found in environments of natural occurrence of the species, can make collection of leaves more viable whether obtaining alkaloidrich extracts is the purpose of the pharmaceutic industry. The production of herbal drugs from leaves will facilitate the management of the species, since a 10-year interval, which is required to withdrawn bark from the stems, is a considerably long time. In addition, withdrawal of leaves causes less damage to the plant phytosanitary status and preservation.

Regarding the presence and absence of pentacyclic and tetracyclic alkaloids, both species have chemotypes that also vary according to the time of year in which the plant is collected (PEÑALOZA et al., 2015; REINHARD, 1999). Although the secondary metabolites present in $\boldsymbol{U}$. tomentosa and $\boldsymbol{U}$. guianensis are similar, some substances are produced by one but not by the other, e.g., the flavonoid kaempferitrin, which is present in the leaves and branches of $\boldsymbol{U}$. guianensis, which has been considered a chemical marker able to distinguish these species (VALENTE et al., 2009). Another important cytogenetic difference between them is that $\boldsymbol{U}$. guianensis has larger chromosomes and more heterochromatin in the cell nucleus (TEPPNER et al., 1984).

In addition to the taxonomic, chemical, and cytogenetic differences, there is also a clear distinction regarding the economic value assigned to these species. $\boldsymbol{U}$. tomentosa is more commercialized and; therefore, has a higher value in the market than $\boldsymbol{U}$. guianensis. Despite this difference, extracts of both species are widely produced by various industries. Thirteen patents involving these species are registered in the United States Patent and Trademark Office (USPTO, 2015).

Whereas Peru and the USA started commercialization, pharmacological studies, and patent development with these species in the 80's, Brazil began to consider the importance of these genetic resources (which are abundant in the Brazilian Amazon forest) only in 2000. Then the extractive exploitation was initiated and these species were included in lists of priority plants in the herbal medicine programs of the Ministry of Health.

The importance of knowing the production chain of medicinal plants is described in the guidelines of the National Policy of Medicinal Plants and Herbal Drugs (BRASIL, 2013). However, development of this subject for the species $\boldsymbol{U}$. guianensis and $\boldsymbol{U}$. tomentosa could be higher. BLAS (1999) described, in part, the production chain of $\boldsymbol{U}$. tomentosa in a 10-ha area in the native community of Bajo Naranjillo (Peru). The study included a forest inventory and a management plan based on the regrowth capacity of the species. A withdrawal of $740 \mathrm{~kg}$ of bark per ha was estimated for a natural forest with a ten-year pruning cycle.

The bark of Uncaria has been commercialized with widely varying prices. In Peru (1996-1998), about 300ton of dry bark were purchased from the local communities by US $\$ 0.90$ and exported to the USA by US $\$ 3.90$ (prices per $\mathrm{kg}$ ). According to the Ministry of Agriculture of Peru, about 135ton of cat's claw were exported in 2000 (SPIEGELFELD, 2005; MIRANDA, 2005). In Brazil (State of Acre), the export of $\boldsymbol{U}$. tomentosa was intensified since 2000 and the plant crop was estimated to be 20ton per year (LIMA, 2005).

In general, the profit from commercializing forest products, which were collected extractivistically 
by traditional communities, did not reach the hands of these ethnic groups. It remains concentrated in the hands of agents who send the raw material to the industry and/or large distribution centers.

Thus, the objective of this review was to gather information about $\boldsymbol{U}$. tomentosa and $\boldsymbol{U}$. guianensis dispersed in the literature, and suggest priority research areas that should be a funding target to make possible crop and preserve these species.

\section{DEVELOPMENT}

\section{Uncaria tomentosa (WILLD.) DC}

Some authors considered that the species

Uncaria tomentosa was originated in Peru and Colombia (MAC BRIDE, 1936). It was described for the first time as Nauclea aculeata HBK, and only in 1830 it was named Uncaria tomentosa, as it is currently known. The term "tomentosa" comes from the observation of prominent ribs, with the appearance of fine veins in the abaxial surface of the leaves (VILCHES, 1997).

It is popularly known as cat's nail (DESMARCHELIER et al., 1997), a designation related to plant morphology. It has thorns on the stem, which are similar to nails (CHENG et al., 2007); although, it also has other popular names such as gabarato (DE FEO, 1992) vilcacora, samento (FALKIEWICZ \& LUKASIAK, 2001), saventário (REINHARD, 1999), “jupindá” and "espera-ai” (PEREIRA \& LOPES, 2006).

Figure 1 shows that leaves are perennial, flowers are yellow-white, and the thorns are sharp and of woody consistency, which facilitate their adherence to tree bark and branches (KEPLINGER et al., 1999; GANZERA et al., 2001). It is a giant climbing plant, whose height may reach $10-30 \mathrm{~m}$ in the adult plant (MIRANDA et al., 2001).

The diameter at the base of the liana varies in the range $5-40 \mathrm{~cm}$ in adult plants that have already flourished (GUEVARA, 1995). Individuals with diameter at breast height (DAP) $5-8 \mathrm{~cm}$ provide on average $0.3-0.5 \mathrm{~kg}$ of dry bark. Plants with such diameters usually have 20 to 25 -m length, and yield $8-10 \mathrm{~kg}$ of dry bark (MIRANDA et al., 2001; SILVA, 2008). The liana's bark is used for at least 2000 years in the traditional medicine of some Peruvian tribes, especially the Asháninka (PILARSKI et al., 2006), a people to whom the name Kampa is also assigned (PIMENTA, 2005).

A survey for the occurrence of $\boldsymbol{U}$. tomentosa was performed in the micro-region of the Jurua river valley (Acre), which includes the High
Pentecost (in the city of Cruzeiro do Sul), Seringal São Salvador (in Mâncio Lima), and Asháninka Indian Reservation (in Marechal Traumaturgo) communities. In these areas, the production of dry bark $\left(13 \mathrm{~kg} \mathrm{ha}^{-1}\right)$ was estimated. A mean diameter $(5.4 \mathrm{~cm})$ was calculated for plants, and different numbers of individuals per hectare were observed in floodplain (17), secondary forest (44), and mainland (1) (MIRANDA et al., 2003).

The initial development of plants are affected by shading levels. Conditions of 55-60\% shade favor the development in height and biomass accumulation (LUNZ et al., 2014). U. tomentosa has a positive phototropism, and luminosity required for the development of younger individuals located in areas of natural regeneration (CANALESSPRINGETT et al., 2013a).

Plant growth (in height) is not influenced by rainfall levels and altitude. However, it is influenced mainly by fertility of the soil, which should be rich in organic matter, specific elements $(\mathrm{N}, \mathrm{P}, \mathrm{K}, \mathrm{Ca}$, and $\mathrm{Mg}$ ), and $\mathrm{pH}$ in the range 5.3-6.1 (TOREJÓN \& QUILIANO, 2007; MECHÁN et al., 2007).

Different periods were observed for flowering (around September), fruiting and maturation of fruits (Oct-Nov), and seed dispersal (Jan-Feb). Insects are the main pollinating agents, and fruit development (until the maturity stage) occurs within 6-8 weeks after pollination. The species is evergreen, and the seed production cycle is annual (FLORES, 1995; MIRANDA et al., 2001).

The seedling production by seeds is viable. However, plants produced by sexual propagation show a significant chemical variability. Seeds have a variable size $(2-4 \mathrm{~mm})$, and they are photoblastic positive. They may be preserved in cold room $\left(10^{\circ} \mathrm{C}\right)$ when stored in paper bags and dry and dark conditions. The viability is lost after $10(65-84 \%)$ and $120(47-58 \%)$ days of storage in temperatures lower than $25^{\circ} \mathrm{C}$ (GUEVARA,1995; INDACOCHEA \& POLLITO, 1999).

In addition to seed propagation, multiplication can also be obtained by the micropropagation technique, which is seen as promising to obtain large-scale plants with industrial interest. In this context, various descriptions of in vitro insertion of $\boldsymbol{U}$. tomentosa are available. However, a micropropagation protocol showing the production viability on a commercial scale, e.g., using a temporary immersion system was not yet published (FERIAROMERO et al., 2005; PEREIRA et al., 2006; LUNA-PALENCIA et al., 2013). 


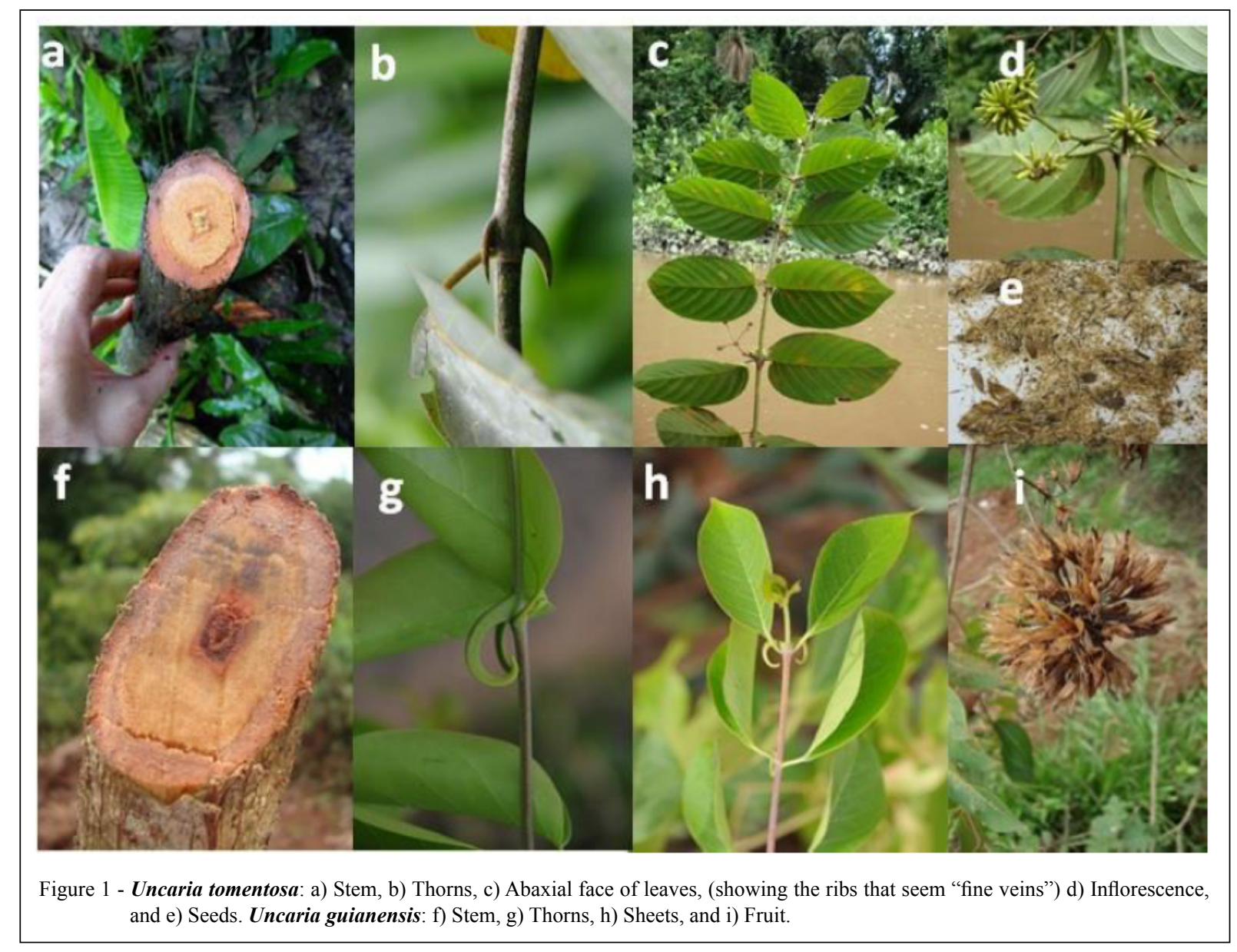

Total alkaloid content in micropropagated plants after acclimatization varies according to age, and plants aged six months produce more than seedlings aged 2 months or 2 years. The content of tetracyclic alkaloids is higher in younger seedlings, whereas the pentacyclic alkaloids accumulate more in older plants (LUNA-PALENCIA et al., 2013).

Clone production by biotechnological techniques is certainly the most viable alternative to ensure standardization of raw material from the Uncaria species. In addition to the chemical variability found between individuals, there is a report that three varieties of $\boldsymbol{U}$. tomentosa were found to be different from each other only by color of their freshly-cut cortex and root. Thus, colors are classified as liber whitish gray, yellowish brown, and dark red (KEPLINGER, 1982). Although this description is important, it is not included in the monographs of the American (AMERICAN HERBAL
PHARMACOPEIA, 1997) and British (BRITISH HERBAL PHARMACOPEIA, 1989) Pharmacopeia, and the Hages Handbuch der Pharmazeutischen Praxis (STRUM et al., 1999).

Ethnopharmacological studies performed with the species showed that it is popularly used in the treatment of abscesses, asthma, arthritis, skin and infectious diseases, deep wounds, gastritis, general inflammation, rheumatism, malignant tumors, gastric ulcers, postpartum recovery, prevention of general diseases, kidney cleansing, and menstrual cycle irregularities (AQUINO et al., 1991; DE FEO, 1992; AQUINO et al., 1997; SHENG et al., 1998; KEPLINGER et al., 1999; CUNHA et al., 2003; GARCIA PRADO et al., 2007; LORENZI \& MATOS, 2008).

In addition to the ethnopharmacological data, various pharmacological tests performed in vitro and in vivo confirmed its antioxidant 
(DREIFUSS et al., 2013), anticancer (PILARSKI et al., 2010), anti inflammatory (ROJAS-DURAN et al., 2012), antimicrobial (CCAHUANA-VASQUEZ et al., 2007), antiherpetic (CAON et al., 2014), contraceptive (NOGUEIRA NETO et al., 2011), neuroprotective (SHI et al, 2013), and antidiabetic (DOMINGUES et al., 2011) activities.

There is a consensus that a single substance or a single class of secondary metabolite being responsible for all pharmacological activities assigned to the species is unlikely. However, the pentacyclic oxindole alkaloids are considered chemical markers. Among them, uncarin, pteropodin, mitraphylline, speciophylline, isopteropodin, and isomitraphylline are highlighted (LAUS et al., 1997).

Due to the traditional use, pharmacological research confirming therapeutic efficacy, as well as phytochemical and analytical studies that enable the control over the quality of medicines produced from $\boldsymbol{U}$. tomentosa, which has been stimulated by Brazilian government programs aiming primary health care. Thus, $\boldsymbol{U}$. tomentosa was included in the list of plants described in the monographs on medicinal plants as published by the World Health Organization (WHO, 1997) and in the List of Essential Medicines published by the Brazilian government (RENAME) (BRAZIL, 2013).

\section{Uncaria guianensis (Aubl.) J.F. Gmel}

The species was described for the first time in the Guyanas (1775) as Ourouparia guianensis (Aublet). Two decades later, this nomenclature was changed to Uncaria guianensis, which remains unchanged so far (VILCHES, 1997). It is popularly known as uña de gato, uña de gavilán, gabarato colorado, gabarato casha (ARELLANO, 1994), unganangui (RUTTER, 1990), tambor huasca, ancayacu (GENTRY, 1993), Paraguayo, and ancajsillo (VILCHES, 1997). It is a climbing plant (height: $5-10 \mathrm{~m}$; base diameter: $4-15 \mathrm{~cm}$ ). Its liana is more creeping than climbing (Figure 1) because its thorns (with tip bent inward) impair its adherence to other plants (GUEVARA, 1995).

Different time periods were observed in the Peruvian forest for flowering (Feb-May) and fruiting (Apr-Jun) (FLORES, 1995; QUEVEDO, 1995), and in the Juruá river valley (Acre) for flowering (Feb-Apr), fruiting (May-Jun), and fruit maturation and seed dispersion (MayAug) (MIRANDA et al., 2001). U. guianensis can propagate by seeds. Their germination are variable (25-85\%) (GUEVARA, 1995; PEREIRA $\&$ LOPES, 2006) and can reach $90 \%$ when the seeds are introduced in vitro (PEREIRA et al., 2006). According to a study, plants that growedfrom seeds presented great variability regarding morphology and content of secondary metabolites (TORREJÓN, 1997).

The alkaloid content in Uncaria varies between both individuals and different plant parts. This could be explained by the fact that the extracts were produced from plant samples collected in regions that are the center of origin of the species and; therefore, they have a considerable genetic diversity and chemical variability. Production of extracts from too much diversified herbal drugs hampers established quality standards for herbal drugs by the industry. In this context, the use of biotechnological techniques such as micropropagation are indicated for scaled production of elite clones, which are highly productive in terms of biomass and content of metabolites of interest.

A study on the occurrence of $\boldsymbol{U}$. guianensis was conducted in the micro-region of the Juruá river valley and showed an estimated dry bark production of $199 \mathrm{~kg} \mathrm{ha}^{-1}$, which is 15 times greater than that estimated for $\boldsymbol{U}$. tomentosa. The average diameter $(2.8 \mathrm{~cm})$ of plants and the number of individuals per hectare in floodplain (62), secondary forest (97), and mainland (4.8) were calculated (MIRANDA et al., 2003).

The natural regeneration of $\boldsymbol{U}$. guianensis in anthropized areas are influenced by the amount of light that arrives at the under storey or ground vegetation. This factor is especially significant for higher plants, but the amount of light does not need to be abundant (CANALES-SPRINGETT et al., 2013b). As can be seen, the number of studies available in the scientific literature on the species $\boldsymbol{U}$. guianensis is much smaller than that on $\boldsymbol{U}$.tomentosa.

\section{CONCLUSION}

In Brazil, as in other countries, the use of and interest in Uncaria tomentosa is greater than those in Uncaria guianensis. However, the species $\boldsymbol{U}$. tomentosa has a more restricted geographical distribution and occurs in more limited geo environments. It is important to investigate from the pharmacological point of view whether both species can be used for the same therapeutic purpose. If this assumption is confirmed, then cultivation of $\boldsymbol{U}$. guianensis should be a priority, since its characteristics are more favorable to cultivation and management, e.g., non-sharp thorns and adaptation to environments with more drained and less fertile soils. 
The Brazilian Ministry of Health and global pharmaceutical industry have a growing demand for raw material from $\boldsymbol{U}$. tomentosa and $\boldsymbol{U}$. guianensis. Although a reasonable number of phytochemical and pharmacological studies on these species can be reported, there is a lag regarding the agronomic researches, which are still preliminary, few and rather inconsistent. This scenario indicates that from this point of view almost everything has to be done.

Reports on areas cultivated with $\boldsymbol{U}$. tomentosa and $\boldsymbol{U}$. guianensis do not exist, and all raw materials for drug production are obtained in the extractivist mode, which impairs the genetic diversity and survival in natural environments. Thus, research in the genetic (conservation and diversity) and phytotechny (management, propagation, and cultivation) areas, should be a priority to enable large-scale production of both species.

\section{ACKNOWLEDGEMENTS}

Coordenação de Aperfeiçoamento de Pessoal de Nível Superior (CAPES) and Universidade de Ribeirão Preto (UNAERP).

\section{REFERENCES}

AMERICAN HERBAL PHARMACOPEIA. Herbal Gramatica. Scotts Valley, CA, 1997. 40.

AQUINO, R. et al. Plant metabolites. New compounds of antiinflammatory activity of Uncaria tomentosa. Journal of Natural Products, v.54, p.453-459. 1991. Available from: $<$ http://pubs.acs. org/doi/pdf/10.1021/np50074a016>. Accessed: Sept. 21, 2014 doi: $10.1021 / \mathrm{np} 50074 \mathrm{a} 016$

AQUINO, R. et al. Triterpenes and quinovic acid glycosides from Uncaria tomentosa. Phytochemistry, v.45, p.1033-1040, 1997. Available from: <http://www.sciencedirect.com/science/article/pii/ S0031942296007169>. Accessed: Sept. 21, 2014. doi: 10.1016/ S0031-9422(96)00716-9.

ARELLANO, P. Instituto Nacional de Medicina Tradicional. Lima: Ministerio de Salud, 1994. 122p.

BRASIL. Ministério da Saúde, Portal da Saúde (SUS). Relação nacional de medicamentos essenciais (RENAME), 2013. Available from: $<$ http://portalsaude.saude.gov.br/images/pdf/2014/ setembro/29/Rename-2013.pdf>. Accessed: Sept. 29, 2014.

BRITISH Herbal Pharmacopeia. Bournamouth: British Herbal Medicine Association, p.318-321. 1989.

CANALES-SPRINGETT, A.W. et al. Respuesta de la regenaración natural de la Uncaria tomentosa (Willd) D.C. "Uña de gato", al efecto de la luz en ecosistemas boscosos primários intervenidos dentro del bosque nacional Alexander Von Humboldt, Pucallpa, Perú. Ecología Aplicada, v.12, n.2, p.99-109, 2013a. Available from: <http://www.scielo.org.pe/pdf/ecol/v12n2/a05v12n2.pdf >. Accessed: Sept. 15, 2015.
CANALES-SPRINGETT, A.W. et al. Respuesta de la regenaración natural de la Uncaria guianensis (Aubl.) J.F. Gmel "Uña de gato", al efecto de la luz em bosques sencundarios dentro del bosque nacional Alexander Von Humboldt, Pucallpa, Perú. Ecologia Aplicada, v.12, n.2, p.111-120, 2013b. Available from: <http://www.scielo. org.pe/scielo.php?pid=S1726-22162013000200006\&script $=$ sci arttext>. Accessed: Sept. 15, 2015

CAON, T. et al. Antimutagenic and antiherpetic activities of different preparations from Uncaria tomentosa (cat's claw). Food and Chemical Toxicology, v.66, p.30-35, 2014. Available from: $<\mathrm{http}: / /$ www.sciencedirect.com/science/article/pii/S0278691514000271>. Accessed: Oct. 12, 2014. doi: 10.1016/j.fct.2014.01.013.

CCAHUANA-VASQUEZ, R.A. et al. Antimicrobial activiy of Uncaria tomentosa against oral human pathogens. Brazilian Oral Research, v.21, n.1, p.46-50, 2007. Available from: $<$ http://dx.doi. org/10.1590/S1806-83242007000100008>. Accessed: Oct. 14, 2014. doi: $10.1590 / \mathrm{S} 1806-83242007000100008$

CHENG, F.J. et al. Induction of apoptosis by Uncaria tomentosa through reactive oxygen species production, cytochrome $\mathrm{c}$ release, and caspases activation in human leukemia cells. Food Chemistry and Toxicology, v.45, p.2206-2218, 2007. Available from: <http:// www.sciencedirect.com/science/article/pii/S0278691507001792>. Accessed: Jun. 02, 2014. doi: 10.1016/j.fct.2007.05.016.

CUNHA, A.P. et al. Plantas e produtos vegetais em fitoterapia. 2.ed. Lisboa: Serviço de Educação e Bolsas, Fundação Calouste Gulbenkian, 2003. 702p.

DE FEO, V. Medicinal and magical plants in the northern Peruvian Andes. Fitoterapia, v.63, p.417-440, 1992. Available from: <http://www.samorini.it/doc1/alt_aut/ad/defeo2.pdf $>$. Accessed: Apr. 05, 2014.

DESMARCHELIER, C. et al. Evaluation of the in vitro antioxidant activity in extracts of Uncaria tomentosa (Willd.) DC. Phytotherapy Research, v.11, p.254-256, 1997. Available from: <http://onlinelibrary.wiley.com/doi/10.1002/(SICI)1099573(1997 05)11:3\%3C254::AI-PTR76\%3E3.0.CO;2-5/pdf>. Accessed: Sept. 14, 2014. doi: 10.1002/(SICI)1099-1573(199705)11:3<254::AIDPTR76>3.0.CO;2-5.

DOMINGUES, A. et al. Prevention of experimental diabetes by Uncaria tomentosa extract: Th2 polarization, regulatory $\mathrm{T}$ cell preservation or both? Journal of Ethnopharmacology, v.137, p.635-642, 2011. Available from: <http://www.sciencedirect.com/ science/article/pii/S0378874111004387>. Accessed: Sept. 21, 2014. doi: 10.1016/j.jep.2011.06.021.

DREIFUSS A.A. et al. Uncaria tomentosa exerts extensive antineoplastic effects against the Walker-256 tumour by modulating oxidative stress and not by alkaloid activity. Plos one, v.8, n.2, p.1-14, 2013. Available from: <http://www.plosone.org/article/ fetchObject.action?uri=info:doi/10.1371/journal.pone.0054618 \&representation=PDF $>$. Accessed: Dec. 12, 2014. doi: 10.1371/ journal.pone.0054618.

DWYER, J.D. Annals of the Missouri Botanical Garden, Flora do Panamá. Familia 179. Rubiaceae. v.67, $1^{\circ}$ y $2^{\circ}$ parts, p.1-522, 1980.

FALKIEWICZ, B.; LUKASIAK, J. Vilcacora [Uncaria tomentosa (Willd.) DC. and Uncaria guianensis (Aublet) Gmell.] - a review of published scientific literature. Case Reports and Clinical 
Practice Revue, v.2, p.305-316, 2001. Available from: <http:// amjcaserep.com/abstract/index/idArt/475352>. Accessed: Dec. 05, 2014. doi: 475352

FERIA-ROMERO, I. et al. Iduced accumulation of oleanolic acid and ursolic acid in cell suspension cultures of Uncaria tomentosa Biotechnology Letters, v.27, n.12, p.839-843, 2005. Available from: <http://link.springer.com/article/10.1007/s10529-005-62157>. Accessed: Nov. 06, 2014. doi: 10.1007/s10529-005-6215-7.

FLORES Y. Propagación por semillas de la "Uña de Gato" Pucallpa, Perú: Instituto Nacional de Investigación Agraria, 1995. 51p. (Boletín Técnico, 5).

GANZERA, M. et al. Improved method for the determination of oxindole alkaloids in Uncaria tomentosa by high performance liquid chromatography. Planta Medica, v.67, p.447-450, 2001. Available from: <https://www.thieme-connect.com/products/ ejournals/pdf/10.1055/s-2001-15824.pdf>. Accessed: Oct. 17, 2014. doi: $10.1055 / \mathrm{s}-2001-15824$

GARCIA, E.P. et al. Antiproliferative effects of mitraphylline, a pentacyclic oxindole alkaloid of Uncaria tomentosa on human glioma and neuroblastoma cell lines. Phytomedicine, v.14, p.280-284, 2007. Available from: <http://www.sciencedirect.com/ science/article/pii/S0944711306002443>. Accessed: Aug. 01, 2014. doi: 10.1016/j.phymed.2006.12.023.

GENTRY, A.H. A field guide to the families and genera of woody plants of Northwest South America (Colombia, Ecuador, Perú) with supplementary notes on Herbaceous taxa. Washingthon DC,University of Chicago Press, 1993. 895p.

GUEVARA, A.Q. Silvicultura de la Uña de Gato- Alternativa para su conservación. Pucalipa-Perú: Instituto de Investigaciones de la Amazonía Peruana, 1995. 43p.

INDACOCHEA, I.L.; POLLITO, P.Z. Guia para el cultivo, aprovechamiento y conservación de la uña de gato Uncaria tomentosa (Willd. Ex Roemer \& Schultes) De Candolle. Santafé de Bogotá, SECAB, Ciencia y Tecnologia, 1999. 49p. (N.75).

KEPLINGER, K. Cytostat, contraceptive and antiinflammatory agent from Uncaria tomentosa roots. Patent - PCT Int. Appl WO - 82 01, 130. p 27, 1982.

KEPLINGER, K. et al. Uncaria tomentosa (Willd.) DC.Ethnomedicinal use and new pharmacological, toxicological and botanical results. Journal of Ethnopharmacology, v.64, p.23-24, 1999. Available from: <http://www.sciencedirect.com/science/ article/pii/S0378874198000968>. Accessed: Oct. 10, 2014. doi: $10.1016 / \mathrm{S} 0378-8741(98) 00096-8$

KLEIN, T. et al. Fitoterápicos: um Mercado promissor. Revista de Ciências Farmacêuticas Básicas e Aplicada, v.30, n.3, p.241-248. 2009. Available from: <http://serv-bib.fcfar.unesp.br/ seer/index.php/Cien Farm/article/view/713/888>. Accessed: 27 Nov. 2014

LAUS, G. Advances in chemistry and bioactivity of the genus Uncaria. Phytotherapy Research, v.18, p.259-274, 2004 Available from: <http://onlinelibrary.wiley.com/doi/10.1002/ ptr.1469/pdf>. Accessed: Nov. 18, 2014. doi: 10.1002/ptr.1469.

LAUS, G. et al. Alkaloids of Peruvian Uncaria tomentosa Phytochemistry, v.45, p.855-860, 1997. Available from: <http://
www.sciencedirect.com/science/article/pii/S0031942297000617>. Accessed: Aug. 28, 2014. doi: 10.1016/S0031-9422(97)00061-7.

LIMA, V. Mercado se abre para negócios das plantas amazônicas. 2005. Available from: <http://ac.gov.br>. Accessed: May 27, 2015

LORENZI, H. et al. Plantas medicinais no Brasil: nativas e exóticas. 2.ed. Nova Odessa: Instituto Plantarum, 2008. 544p.

LUNA-PALENCIA, G.R. et al. Differential alkaloid profile in Uncaria tomentosa micropropagated plantlets and root cultures. Biotechnology Letters, v.35, p.791-797, 2013. Available from: $<$ http://link.springer.com/article/10.1007/s10529-012-11288\#page-1>. Accessed: Dec. 10, 2014. doi: 10.1007/s10529-012$1128-8$.

MAC BRIDGE, JF. Flora del Perú. Field Museum of Natural History Botany, v.13, p.11-12, 1936

MARTINS, E.R. et al. Plantas medicinais. Viçosa: UFV, 2003. 220p.

MECHÁN, T.E. et al. Influencia de la variabilidad edafica en la produccion de biomasa del cultivo de la uña de gato Uncaria tomentosa (Willd) D.C. en la cuenca del rio Aguaytia, Region Ucayali-Peru. Ecologia Aplicada, v.6, n.1, 2, p.33-37, 2007. Available from: <http:/www.scielo.org.pe/scielo.php?pid=S172622162007000100004\&script $=$ sci_arttext $>$. Accessed: Dec. 01, 2014. doi: 2002-5474

MIRANDA, E.M. Cat's claw- Uncaria tomentosa (Willd. ex Roem. \& Schult.) D.C. and Uncaria guianensis (Aubl.) J.F. Gmel. In: SHANLEY, P.; MEDINA, G. Frutíferas e plantas úteis na vida Amazônica. Belém: CIFOR, Imazon, 2005. p.141-146.

MIRANDA, E.M. et al. Caracterização e avaliação de populações nativas de unha-de-gato [Uncaria tomentosa (Willd. ex Roem. \& Schult.) D.C. and Uncaria guianensis (Aubl.) J.F. Gmel.] no vale do rio Juruá-AC. Revista Brasileira de Plantas Medicinais, v.5, n.2, 9.41-46, 2003

MIRANDA, E.M. et al. Subsídios técnicos para o manejo sustentável da unha de gato (Uncaria spp.) no Vale do Rio Juruá, AC. Emprapa Acre: Ministério da agricultura, Pecuária e Abastecimento, Embrapa, Brasil. 2001. p.24. (Documentos 68)

MUR, E. et al. Randomized double blind trial of an extract from the pentacyclic alkaloid-chemotypeos Uncaria tomentosa for the treatment of rheumatoid arthritis. Journal of Rheumatology, v.29, p.656-658, 2002.

NOGUEIRA NETO, J.P. et al. Contraceptive effect of Uncaria tomentosa (cat's claw) in rats with experimental endometriosis. Acta Cirúrgica Brasileira, v.26, n.2, p.15-19, 2011. Available from: $\quad<$ http://dx.doi.org/10.1590/S0102-86502011000800004>. Accessed: Nov. 10, 2014. doi: 10.1590/S0102-86502011000800004.

PAVEI C. et al. HPLC-PDA method for quinovic acid glycosides assay in Cat's claw (Uncaria tomentosa) associated with UPLC/QTOF-MS analysis. Journal of Pharmaceutical and Biomedical Analysis, v.62, p.250-257, 2002. Available from: <http://www. sciencedirect.com/science/article/pii/S0731708511007382>. Accessed: Sept. 29, 2015. doi: 10.1016/j.jpba.2011.12.031.

PEREIRA, R.C.A. et al. Germinação, avaliação do ácido giberélico e posição do explante no alongamento in vitro de Uncaria 
guianensis (Aublet) Gmelin Rubiaceae (Unha-de-gato). Ciências Agrotécnica, v.30, n.4, p.637-642, 2006. Available from: <http:// www.scielo.br/pdf/cagro/v30n4/v30n4a07.pdf >. Accessed: Nov. 08, 2014. doi: v30n4/v30n4a07.

PEREIRA, R.C.A.; LOPES, J.V.M. Aspectos botânicos, etnobotânicos, agronômicos e fitoquímicos de unha-de-gato. Fortaleza, CE, Embrapa Agroindústria Tropical, 2006. $34 \mathrm{p}$. (Documentos, 105).

PILARSKI, R. et al. Anticancer activity of the Uncaria tomentosa (Willd.) DC. preparations with different oxindole alkaloid composition. Phytomedicine, v.17, p.1133-1139, 2010 Available from: $<$ http://www.sciencedirect.com/science/article/pii/ S0944711310001467>. Accessed: Dec. 18, 2014. doi: 10.1016/j. phymed.2010.04.013.

PILARSKI, R. et al. Antioxidant activity of ethanolic and aqueous extracts of Uncaria tomentosa (Willd.) DC. Journal of Ethnopharmacology, v.104, p.18-23, 2006. Available from: <http://www.sciencedirect.com/science/ article/pii/S0378874105005854>. Accessed: Dec. 08, 2014. doi: $10.1016 /$ j.jep.2005.08.046.

PIMENTA, J. Ashaninka, Enciclopédia Povos Indígenas no Brasil. ISA (Instituto Sócio Ambiental). Available from: $<\mathrm{http}: /$ www.socioambiental.org/pib/epi/ashaninka/nome.shtm.2005>. Accessed: Oct. 10, 2012

PUBMED. Available from: <http://www.gopubmed.com/web/ gopubmed/>. Accessed: Dec. 12, 2014.

QUEVEDO, G.A. Silvicultura y manejo de la "uña de gato". Pucallpa: Instituto de Investigaciones de la Amazonia PeruanaIIAP, 1995. 43p

QUIROZ, J.D.Z. Nuevos aspectos en el estudio agronómico y fitoquímico de las dos espécies peruanas del gênero Uncaria: Uncaria tomentosa (Willd) DC. y la Uncaria guianensis (Aulb). Gmel-Uña de Gato. Available from: <http://www.agroselva.com>. Accessed: Oct, 21, 2014.

REINHARD, K.H. Uncaria tomentosa (Willd.) DC.: Cat'sclaw, uña de gato or seventaro. Journal of Alternative and Complementary Medicine, v.5, p.143-151, 1999. Available from: <http://online. liebertpub.com/doi/pdfplus/10.1089/acm.1999.5.143>. Accessed: Jan. 06, 2015. doi: 10.1089/acm.1999.5.143.

ROJAS-DURAN, R. et al. Anti-inflammatory activity of Mitraphylline isolated from Uncaria tomentosa bark. Journal of Ethnopharmacology, v.143, p.801-804, 2012. Available from: <http://www.sciencedirect.com/science/ article/pii/S0378874112004849>. Accessed: Dec. 01, 2014. doi: $10.1016 /$ j.jep.2012.07.015.

RUTTER, A.R. Catálogo de plantas utiles de la Amazonía Peruana. Yarinacocha, Pucallpa: Ministerio de Educación Instituto Linguistico de Verano, 1990. 369p.

SCHULTES, R.E.; RAFFAUF, R.F. The healing forest medicinal and toxic plants of the Northwest Amazonia. In: Foreword by HRH Prince Philip, Duke of Edinburgh. Historical, Ethno and Economic Botany Series. Dioscórides: Press-Portland, 1990. v. 2, p.401-403.

SHENG Y. et al. An active ingredient of cat's claw water extracts identification and efficacy of quinic acid. Journal of
Ethnopharmacology, v.96, p.577-584, 2005. Available from: $<$ http:// www.sciencedirect.com/science/article/pii/S0378874104005094>. Accessed: Sept. 29, 2015. doi: 10.1016/j.jep.2004.10.002.

SHENG Y. et al. Induction of apoptosis and inhibition of proliferation on human tumor cells treated with extract of Uncaria tomentosa. Anticancer Research, v.18, p.3363-3368, 1998. Available from: <http://europepmc.org/abstract/med/9858909>. Accessed: Dec. 01, 2014. doi: 18(5A):3363-3368.

SHI, Z. et al. Neuroprotective effects of aqueous extracts of Uncaria tomentosa: Insights from 6-OHDA induced cell damage and transgenic Caenorhabditis elegans model. Neurochemistry International, v.62, p.940-947, 2013. Available from: <http://www.sciencedirect.com/science/article/ pii/S0197018613000739>. Accessed: Nov. 21, 2014. doi: 10.1016/j.neuint.2013.03.001

SHUNKE, V.J. Cultivo de la "uña de gato". In: FORUM NACIONAL DE UÑA DE GATO, 1998, Lima, Pe. Resumenes.. Lima, Perú: Instituto de Desarrollo Rural Peruano, 1998. 30p.

SILVA, M.C. et al. Estimativa do rendimento de casca de unha-de-gato (Uncaria tomentosa (Wild. ex Roem. \& Schult)) na regional do Juruá, Acre. In: SEMINÁRIO DO PROJETO KAMAKAIA MANEJO SUSTENTÁVEL DE PRODUTOS FLORESTAIS NÃO MADEIREIROS NA AMAZÔNIA, 2008, Rio Branco, Acre. Anais... Rio Branco: Embrapa Acre, p.169176. 2008.

SOUKUP, J. Vocabulario de los nombres tradicionales de la Flora Peruana y catálogo de los géneros. Lima: Editorial Salesiana, 1987. 436p.

SPIEGELFELD, C. Cat's claw herbal remedy. Trade \& Enviromental Database (TED) Case Studies, v.15, n.1, p.772, 2006. Available from: <http://www.american.edu/ted/cats-clawhtm>. Accessed: May 27. 2015.

STRUM, S. et al. Uncaria tomentosa-Wurzelrinde. In: BLASCHEK, W.R. et al. Hagers handbuch der pharmazeutischen praxis. Germany: Springer-Verlag, 1999. V.2., p.706-710.

TEPPNER, H. et al. Kariosystematik von Uncaria tomentosa und Uncaria guianensis Botanisches aus Pozuzo, Perú I. Phyton, v.24, n.1, p.125-134, 1984. Available from: <http://www.landesmuseum. at/pdf_frei_remote/PHY_24_1_0125-0134.pdf $>$. Accessed: Jan. 06, 2015. doi: $24 \_1 \_0125-013 \overline{4}$.

TORREJÓN, G.D. Uña de gato y produccion sostenible. Lima: Universidad Nacional Agraria La Molina, 1997. 138p.

TORREJÓN, G.D.; QUILIANO, A.C. Crecimiento de um clon de Uncaria tomentosa (Willd.) D.C. en cuatro condiciones de hábitat en la cuenca del río Aguaytía, Ucayali, Perú. Ecología Aplicada, v.6, n.1, 2, p.39-46, 2007.

USPTO, 2015. United States Patent and Trademark Office. Available from: <http://search.uspto.gov/search?query=Unc aria\&op $=$ Search\&affiliate $=$ web-sdmg-uspto.gov $>$. Accessed: May 27, 2015.

VALENTE, L.M.M. et al. Kaempferitrin from Uncaria guianensis (Rubiaceae) and its potential as a chemical marker for the species. Journal Brazilian Chemistry Society, v.20, n.6, p.1041-1045, 2009. Available from: 
$<$ http://dx.doi.org/10.1590/S0103-50532009000600007>. Accessed: Dec. 01, 2014. doi: 10.1590/S010350532009000600007 .

VILCHES, L.E.O. Género Uncaria-Estudios botanicos, químicos y farmacologicos de Uncaria tomentosa y Uncaria guianensis. 3.ed. Lima-Perú: editora, 169p. 1997.

VOLPATO, A.M.M. Avaliação do potencial antibacteriano de Calendula officinalis (ASTERACEAE) para seu emprego como fitoterápico. 2005. 137f. Tese (Doutorado em Ciências, área de concentração em Química Orgânica) Curso de Pós-graduação em Química, Universidade Federal do Paraná, PR.

WHO (WORLD HEALTH ORGANIZATION). Medicinal Plants Monographs (red. Blumenthal M), Herbal Gram: SalernoPaestum, Italy, V.40, n.38. 1997.

WHO (WORLD HEALTH ORGANIZATION), Draft WHO guidelines on safety monitoring and pharmacovigilance of herbal medicines. Amsterdam, 2003. 82p.
ZEVALLA, A.; ZAVALLOS, P.P. Taxonomía, distribuición geográfica y status del Gênero Uncaria em el Perú. Lima: Universidade Nacional Agrária La Molina, 1996. 103p.

ZEVALLOS, P.P. et al. Agrotecnología para el cultivo de la uña de gato o bejuco de agua. In: MARTÍNEZ, J.V. et al. Fundamentos de agrotecnología para el cultivo de plantas medicinales Iberoamericanas. Santafé de Bogotá: Ciencia y Tecnología para el Desarrollo, 2000. p.463-492.

ZEVALLOS-POLLITO, PA; TOMAZELLO FILHO, M. Levantamento e caracterização de duas espécies do gênero Uncaria schreb. (Rubiaceae) correntes no Estado do Acre, Brasil. Ecologia Aplicada, v.9, n.1, p.19-30, 2010. Available from: <http://www. scielo.org.pe/pdf/ecol/v9n1/a03v9n1.pdf $>$. Accessed: Nov. 01, 2014. doi: 2002-5474.

ZHANG, G. et al. Medicinal uses phytochemistry and pharmacology of the genus Uncaria. Journal of Ethnopharmacology, v.173, p.48-80, 2015. Available from: <http://www.sciencedirect.com/ science/article/pii/S0378874115004195>. Accessed: Aug. 17, 2015. doi: 10.1016/j.jep.2015.06.011. 